AGRICULTURE AND BIOLOGY JOURNAL OF NORTH AMERICA

ISSN Print: 2151-7517, ISSN Online: 2151-7525, doi:10.5251/abjna.2013.4.1.54.66

(C) 2013, ScienceHu $\beta$, http://www.scihub.org/ABJNA

\title{
In vitro anthelmintic potential of Vernonia amygdalina and Secamone africana on gastrointestinal nematodes
}

\author{
Agnes Sarah Nalule ${ }^{1 \star}$, James Mucunu Mbaria ${ }^{2}$, James Wangai Kimenju \\ ${ }^{1}$ School of Veterinary Medicine and Animal Resources, Makerere University, P.O. Box 7062 \\ Kampala, Uganda \\ ${ }^{2}$ Faculty of Veterinary Medicine, University of Nairobi, P.O. Box 29053-00625, Nairobi, Kenya \\ ${ }^{3}$ Faculty of Agriculture, University of Nairobi, P. O. Box 2905300625 Nairobi, Kenya
}

\begin{abstract}
In-vitro studies were conducted to determine the anthelmintic activity of ethanolic and water extracts of Vernonia amygdalina and Secamone africana used by agro-pastoralists in semi-arid land Uganda. The plant materials were collected from Nakasongola district and extracted using $70 \%$ ethanol and water. Efficacy and potency of crude extracts was determined using extracts' serial dilutions ranging $4 \mathrm{mg} / \mathrm{ml}$ to $64 \mathrm{mg} / \mathrm{ml}$ parallel to serial dilutions of albendazole ranging: 6.25 $100 \mathrm{mg} / \mathrm{ml}$ in three replicates. Ascaris suum model was used for the assays. Standard phytochemical methods were used for qualitative phytochemical analysis. The plants' extracts caused a dose-dependent motility inhibition with highest concentration of both ethanolic and water extracts of V.amygdalina causing $90 \%$ inhibition compared with $100 \%$ inhibition caused by albendazole. The corresponding median effective doses of ethanolic, water and albendazole were $5.94 \mathrm{mg} / \mathrm{ml}, 13.70 \mathrm{mg} / \mathrm{ml}$ and $15.12 \mathrm{mg} / \mathrm{ml}$ respectively and significantly differed $\left(F_{(2,53)}\right.$ $=257.43, p=0.001)$. There was a significant difference in motility inhibition in all dose levels $\left(F_{(5,53)}\right.$ $\left.=14.01, \quad P=0.001 ; R^{2}=0.93\right)$. Similarly, the water and ethanolic extracts of $S$. africana caused a $93.3 \%$ and $80 \%$ motility inhibition with median effective doses of $40.08 \mathrm{mg} / \mathrm{ml}$ and $25.41 \mathrm{mg} / \mathrm{ml}$ respectively which also significantly differed $\left(F_{(2,53)}=183.26, p=0.001\right)$. There was also a highly significant difference in motility inhibition in all dose levels $\left(F_{(5,53)}=8.00, \quad P=0.001 ; R^{2}=0.92\right)$. The phytochemical screening revealed presence of tannins, alkaloid, saponins, flavonoids, steroids glycosides, triterpenes, coumarin derivatives, anthocyanocides, anthracenocides, and reducing sugars. In conclusion, V.amygdalina and S.africana are potential sources for novel antihelmintics and the secondary metabolites present justify their ethno-veterinary use.
\end{abstract}

Keywords: Helminths, motility inhibition, Ascaris suum, Nakasongola

\section{INTRODUCTION}

Traditional use of medicinal plants in treatment of animal and human diseases is gaining global interest very fast. In Uganda, rural and urban communities have continued to use or consult medicine-men for remedies to a variety of diseases. Helminths infections are one of the major health conditions affecting humans and livestock although are some of the diseases that herbalist have confident in treating of which they have continued to claim effective. Secamone africana (Oliv.) Bullock (Ascleradaceae) locally called "Akatakura in Luganda" and Vernonia amygdalina Del (Asteraceae) locally called "Omululuza in Luganda" are some of the most used plants in treating gastro-intestinal parasites of both humans and livestock (Nalule et al., 2011a).
Vernonia amygdalina commonly called bitter leaf is a shrub of $2-5 \mathrm{~m}$ tall sometimes a tree to $10 \mathrm{~m}$ that grows in secondary scrub, forest edges, thickets and invades cultivated areas (Katende et al., 1995). In Uganda, the plant is traditionally for medicine, nutriceutical and construction purposes (Tabuti, 2009) as well as for increasing uterine contraction during child birth in human (Kamatenesi and OryemaOringa, 2007). The cold leaves water extract is characteristically very bitter, though the bitterness reduces on boiling (Burkill, 1985). In West and East Africa, $V$. amygdalina is used in treatment of constipation, fever, gastro-intestinal parasites (Nalule et al., 2011a), urinary tract inflammations and as a purgative (Akinpelu, 1999) and as soup vegetable (Aregheore et al., 1998; Yeap et al., 2010). Both water and alcoholic extracts of the stem, bark, roots and leaves are used as a purgative, antimalarial and 
for treatment of eczema (Kupcham, 1971). In western Kenya, the leaf concoction is used to treat local chicken of Ascaridia galli (Siamba et al., 2007). In Tanzania, the local people use the plant to malaria fever, stomache, schistosomiasis, amoebic dysentery, and other intestinal parasites (Huffman and Seifu, 1989). It has also been reported to significantly reduce glucose levels in diabetic patients (Akah and Okafor, 1992; Asuquo et al., 2010). Huffman, 2003 reported the wild chimpanzees use the bitter leaf to relieve stomach pain probably involving internal parasites. Anti-malarial and antihelminthic properties (Abosi and Raseroka, 2003); anti-tumour properties (Izevbige et al., 2004) and hepato-protective activity Arhoghro et al., (2009); Ojiako and Nwanjo 2006) and Anti-bacterial (Hamil et al., 2003) have been demonstrated. Pig farmers use the plant to treat pigs' intestinal parasites (Engel, 2007). The roots of $V$. amygdalina have been used for treatment of gingivitis and toothache (Elujoba et al., 2005).

Secamone africana is a lianar that climbs on trees and bushes; has smooth leaves and produce milky latex on damage. S. africana is common around Lake Victoria area and in Central Africa it can easily be confused vegetatively with Secamone afzelii, the most common Secamone species in West Africa (Kémeuzé, 2010). The plant has been widely used in traditional folk medicine in many parts of Uganda (Tabuti, 2009). The leaves and stems are used as anthelmintic and purgative (Nalule et al., 2011a) and for treatment of hypertension in humans (Hamill et al., 2003). In Ivory Coast, the leaves are used to maintain pregnant women till childbirth, and for treating swellings in children (Zabri et al., 2008). The leaves or leafy twigs of a related species $S$. afzelii are used in West Africa to treat or act as a quick-acting but gentle laxative, treat colic and oedema (Kémeuzé, 2010). In Côte d'Ivoire a leaf infusion is also taken as an antispasmodic and treatment of diarrhoea and excessive purging caused by Anchomanes difformis (Blume) Engl. (Araceae) (Kémeuzé, 2010). It is therefore likely that S.africana could provide similar roles although there are limited experimental studies and documentation on the claims.

Despite several reports on the traditional medicinal use of V.amygdalina and S.africana, experimental reports on anthelmintic efficacy are limited or varied, yet communities continue to claim efficacy. Different studies employing different parasites and methods have revealed different efficacies. Thus one study cannot be used to generalise recommendation on the anthelmintic activity of a single plant species. This study was undertaken to determine in vitro anthelmintic activity of ethanolic and water crude extract on nematode helminths using Ascaris suum model and to determine its qualitative phytochemical composition. The study contributes to the knowledge base of materia medica and strategies for sustainable animal health management and the well-being of people whose livelihoods are livestock based industries.

\section{MATERIALS AND METHODS}

Collection and preparation of plant materials: The whole aerial plant parts of $S$. africana and the leaves of $V$. amygdalina were collected from Nakasongola District of Uganda basing on the study conducted between January and March 2010 (Nalule et al., 2011a). The plants were ranked by the agropastoralists in the district as the most preferred and efficacious. The plants were identified by a botanist in Department of Botany Herbarium of Makerere University. They were sorted out of any extraneous material before they were air dried at room temperature for ten days. On drying all samples were milled into powder, kept in tight lidded containers.

Dosage adopted by community: The amounts of the plant parts used by the community were collected from five individuals. The flesh plant part amounts of each individual were weighed and weights recorded. The individual materials were oven dried at $60^{\circ} \mathrm{C}$ and thereafter re-weighed and the mean weights recorded. The amount of the water solvent used by the community for extracting active ingredient was considered and this was considered in dosage determination.

Extraction of crude plant active ingredients and extraction efficiency determination: Two hundred fifty grams $(250 \mathrm{~g})$ of dry plants material were macerated in $2000 \mathrm{ml}$ of $70 \%$ ethanol for 72 hours with intermittent shaking in duplicates. Filtration through cotton wool was done to remove coarse particles and finely through filter paper (Whatman $\AA$, England). The filtrate was concentrated on Rota-vapor type Buchi-R, Switzerland under reduced pressure at $40^{\circ} \mathrm{C}$. The extracts were transferred to previously weighed kidney and petri dishes and put into an oven to dry completely at $50^{\circ} \mathrm{C}$ to produce solid materials. The mean yield of the duplicate samples were determined and recorded. Thereafter dried extracts were packed into universal bottles and kept at $4^{0} \mathrm{C}$ till needed for bioassay tests. 
Similarly, $250 \mathrm{~g}$ of fresh dried materials of the study plants were soaked in 2liters of distilled water with intermittent shaking for 72 hours. Thereafter, filtering was done to remove coarse material first with cotton wool and finely with Whatman filter paper $(12.5 \mathrm{~mm})$. The filtrate was concentrated under reduced pressure in a rotar evaporator as above. The concentrated filtrates were then evaporated to dryness in an oven at $50^{\circ} \mathrm{C}$ and yield recorded. The water extracts were used shortly after drying to avoid spoilage since it was not freeze dried.

Collection and maintenance of Ascaris suum: Adult Ascaris suum worms were collected from small intestines of pigs obtained from Wambizi slaughter house in Kampala. Immediately after slaughter, adult worms were collected and transported in flask containing Goodwin's solution Lamson and Brown, 1936; Donahue et al. 1981) at about $37^{\circ} \mathrm{C}$ to the pharmacology laboratory, School of Veterinary Medicine, Makerere University. The active worms were selected and washed in warm water at $37^{\circ} \mathrm{C}$ and maintained in Goodwin's solution at $37^{\circ} \mathrm{C}$ before setting the experiment.

Effect of Plant Extracts on Adult Worms: Motility inhibition test was selected due to its suitability for use in field or laboratory settings and ease of parasite identification as well as previous reports of its application to detect resistance to both the benzimidazole and macrocylic lactone drug groups (Gill et al., 1991). In preliminary experiments, a Criteria used for assessing the effects of crude plant extracts on the motility of adult Ascaris suum was developed and combined the procedures described by Kotze et al. (2004); Paolini et al. (2004) and MarieMagdeleine et al. (2009).

Helminth motility inhibition assay experimental design: Eighteen (18) sets of $250 \mathrm{ML}$ conical flasks were grouped into six groups with three replicates each for each plant species. The dosage was adjusted following the preliminary study results and the plant yields. To each of the three flask of group one, $100 \mathrm{ml}$ of Goodwin's solution was added to act as negative control. To groups 2-6 serial dilutions of $S$. africana ethanolic crude plant extract ranging 4 to $64 \mathrm{mg} / \mathrm{ml}$ were added. A similar set was prepared for V. amaygdalina ethanolic extract. In parallel, 18 flasks were also divided into six groups to cater for the negative control and the five level serial dilutions (concentrations from 6.25 to $100 \mathrm{mg} / \mathrm{ml}$ ) of positive control where Albendazole (Valbazen $\AA$ ) $10 \%$ was used. At the end of the experiment, the procedure was repeated with serial dilutions of water crude extract also ranging 4 to $64 \mathrm{mg} / \mathrm{ml}$ of $S$. africana and $V$. amaygdalina respectively. The lowest dose level represents half of the community adopted dosage and on extraction efficiency. Stock solutions were prepared by dissolving a weighed amount of extract in $10 \mathrm{ml}$ of dimethyl sulfoxide (DMSO) then diluted by Goodwin's physiological solution to $600 \mathrm{ml}$ mark to make the highest concentration $(\mathrm{mg} / \mathrm{ml})$ with the same solution. The volumes in each of the flask were made to $100 \mathrm{ml}$ mark of calculated dose to fully submerge the heavy parasites. Ten average size motile adult worms were randomly placed in each of the flask. The flasks and their contents were incubated at $37^{\circ} \mathrm{C}$ and checked for motility at 24 and 48hours during which all the parasites in each flask were assessed for paralysis, death or motility (active) and recorded. A motility index was calculated as the ratio between the numbers of immotile worms/total number worms in each flask of the 3 flask replicates per concentration.

A worm was considered to be motile if it moved in a sinusoidal motion when stimulated by water at $50^{\circ} \mathrm{C}$. Similarly it was considered paralyzed if on stimulating it by water at $50^{\circ} \mathrm{C}$ only part of the body responded either by raising the head and whether some parts showed autolysis and change of colour to pale white. Motility was also assessed using water at $50-60^{\circ} \mathrm{C}$. Death of worms was ascertained by the absence of motility for an observation period of 5-6 seconds. To differentiate dead from paralysed the worm were dipped in water at $60^{\circ} \mathrm{C}$ for 30 seconds that would be followed by sudden regaining of motility for those paralyzed while the dead ones do not respond. The number of motile (alive) and immotile (dead/or paralysed) worms were counted and recorded for each concentration. A mortality index was calculated as the number of dead worms divided by the total number of worms per flask.

Preliminary phytochemical screening: The water and ethanol extracts were qualitatively phytochemically analyzed using the standard methods described by Cieule (1964); Harbone (1973); Mojab et al. (2003) and Tchamadeu et al. (2010) for presence of alkaloids salts (Meyer's and drangedorffs test), tannins (Styassny's reagent), saponins (foaming test), flavonoids (Shibata's reaction), reducing sugars (Fehling's tests), anthracenocides (Borntagen's reaction), coumarins (colour fluorescence under UV light), glycosides and triterpenoids (Liebermann-Burchard's test) and anthocynosides . 
Data analysis and determination of median effective dose $\left(E D_{50}\right)$ : The bioassay data was analyzed by the Generalised Linear Model procedures for regression, Nonlinear regression curves of treatments are defined as; Percentage motility inhibition $(Y)=A+C /\left(1+E X P\left(-B^{*}(X-M)\right)\right)$.

Where; $Y$ is proportion of worm motility inhibited by ethanol, water extracts and albendazole. $A$ is $Y$ intercept; $C$ is the top - bottom of the curve i.e $X=0$ and $X=$ maximum; $B$ is a rate constant expressed as reciprocal of $X ; M$ is random error and $X$ is the dose of treatment (ethanolic, water and albendazole). $\mathrm{ED}_{50}$ determination and percent mean comparisons was carried out using Bonferroni test in the Graph Pad Prism version 5.01 software (Inc San Diego, CA
USA) and Genstat $13^{\text {th }}$ edition, VSN (www.genstat.co.uk). The soft wares were used to determine the means of percent motility inhibition, regression equations and $95 \%$ confidence intervals (Cl) and to generate the dose-response curves. Twoway analysis of variance was carried out and $P$ value $<0.05$ was used for significance level.

\section{RESULTS}

Community adopted dosage and extraction efficiency of the plants: Community adopted dosage, amount of solvent used and extraction efficiency of Vernonia amygdalina and Secamone africana in $70 \%$ ethanol and water solvents are given in Table 1.

Table 1 Community adopted dosage and extraction efficiency (yield) of the plant species in water and $70 \%$ ethanol solvents ( $\mathrm{g} / 250 \mathrm{~g}$ of dry plant material)

\begin{tabular}{|l|l|l|l|l|l|}
\hline Plant name & $\begin{array}{l}\text { Community dry } \\
\text { weights used }(\mathrm{g}) \\
\text { Mean } \pm \text { SEM }\end{array}$ & $\begin{array}{l}\text { Volume of } \\
\text { solvent used } \\
\text { by community }\end{array}$ & $\begin{array}{l}\text { Volume of crude } \\
\text { extract } \\
\text { administered }\end{array}$ & $\begin{array}{l}\text { Water extract yield (g) } \\
\text { Mean } \pm \text { SEM }\end{array}$ & $\begin{array}{l}\text { Ethanol extract } \\
\text { yield (g) } \\
\text { Mean } \pm \text { SEM }\end{array}$ \\
\hline S. africana & $66.30 \pm 6.08$ & $1 \mathrm{~L}$ & $0.3-0.5 \mathrm{~L}$ & $25.00 \pm 1.67^{\mathrm{a}}$ & $52.05 \pm 6.95^{\mathrm{a}}$ \\
\hline V.amygdalina & $65.52 \pm 8.39$ & $3 \mathrm{~L}$ & $0.75-1.5 \mathrm{~L}$ & $39.17 \pm 2.50^{\mathrm{b}}$ & $37.45 \pm 3.95^{\mathrm{b}}$ \\
\hline
\end{tabular}

*Lower amount for calves and small ruminants. All values represent mean \pm standard error of means (SEM); Comparison for significance between the solvents was done using paired sample t-test. ${ }^{\mathrm{a}-\mathrm{b}}$ Means with same superscript in a row are not significant $(p>0.05)$

\section{In vitro anthelmintic activity of ethanolic and water extracts of the plants}

Vernonia amygdalina: After 48 hours of exposure of adult Ascaris suum to different concentrations of plant extracts, both ethanolic and water extracts of plants produced high worm motility inhibition proportions that were dose-dependent compared to the negative control group. The 48 hour percent motility inhibition by different concentrations of both water and ethanolic extracts of V.amygdalina compared with negative control is given in Table 2. The dosage adopted by the community also inhibited worm motility by $23.33 \pm 3.33$ of the parasites by 48 hours post treatment.

There was a significant difference in all dose levels of both plant extracts on motility inhibition that was dose-dependent irrespective of solvent used when compared with negative control observed using generalized linear model $\left(F_{(5,53)}=14.01, P=0.001\right.$; $\left.\mathrm{R}^{2}=0.93\right)$. There was a significant difference in potency of V.amygdalina extracts from the different solvents used in extraction of active ingredients and albendazole $\left(F_{(2,53)}=257.43, p=0.001\right)$. However, comparing the crude extracts on worm motility with $10 \%$ albendazole a conventional anthelmintic drugs commonly used in the study area positive control, there was no significant difference $(p>0.05)$.

The dose response-curve of the ethanolic and water of $V$. amygdalina crude extracts and albendazole revealed that the ethanolic extract was more potent than the water extracts compared with albendazole as demonstrated by the shift of the ethanolic extract curve to the left (Figure1). 
Agric. Biol. J. N. Am., 2013, 4(1): 54-66

Table 2: Effect of concentration of crude extracts of Vernonia amygdalina on motility of Ascaris suum 48 hours post treatment

\begin{tabular}{|c|c|c|c|c|}
\hline \multirow[t]{2}{*}{ Treatment } & \multirow[t]{2}{*}{ Dose $\mathrm{mg} / \mathrm{ml}^{*}$} & \multirow{2}{*}{$\begin{array}{l}\text { \% Motility inhibition } \\
\text { Mean } \pm \text { SEM }\end{array}$} & \multicolumn{2}{|c|}{ 95\%confidence interval } \\
\hline & & & Lower bound & Upper bound \\
\hline $\begin{array}{l}\text { Ethanolic } \\
\text { extract }\end{array}$ & $\begin{array}{l}0.00 \\
4.00 \\
8.00 \\
16.00 \\
32.00 \\
64.00\end{array}$ & $\begin{array}{l}0.00 \pm 0.00 \\
16.67 \pm 6.67 \\
23.33 \pm 3.33 \\
63.33 \pm 3.33 \\
86.67 \pm 8.82 \\
90.00 \pm 5.77\end{array}$ & $\begin{array}{l}-12.24 \\
1.09 \\
11.09 \\
71.09 \\
74.43 \\
77.76\end{array}$ & $\begin{array}{l}12.24 \\
25.57 \\
35.57 \\
95.57 \\
98.91 \\
102.24\end{array}$ \\
\hline $\begin{array}{l}\text { Aqueous } \\
\text { extract }\end{array}$ & $\begin{array}{l}0.00 \\
4.00 \\
8.00^{\text {cd }} \\
16.00 \\
32.00 \\
64.00\end{array}$ & $\begin{array}{l}0.00 \pm 0.00 \\
0.00 \pm 0.00 \\
23.33 \pm 3.33 \\
80.00 \pm 8.82 \\
83.33 \pm 5.77 \\
90.00 \pm 5.77\end{array}$ & $\begin{array}{l}-12.24 \\
-12.24 \\
11.09 \\
67.76 \\
71.09 \\
77.76\end{array}$ & $\begin{array}{l}12.24 \\
12.24 \\
35.57 \\
92.24 \\
95.57 \\
102.24\end{array}$ \\
\hline Albendazole & $\begin{array}{l}0.00 \\
6.25 \\
12.50 \\
25.00 \\
50.00 \\
100.00\end{array}$ & $\begin{array}{r}0.0 \pm 0.00 \\
30.00 \pm 10.0 \\
46.67 \pm 12.20 \\
76.67 \pm 8.82 \\
90.00 \pm 5.77 \\
100.00 \pm 0.00\end{array}$ & $\begin{array}{l}-8.91 \\
17.76 \\
34.43 \\
64.43 \\
77.76 \\
87.76\end{array}$ & $\begin{array}{l}8.91 \\
42.24 \\
58.91 \\
88.91 \\
102.24 \\
112.24 \\
\end{array}$ \\
\hline $\begin{array}{l}{ }^{*} \text { Three replic } \\
\text { solution used }\end{array}$ & treatment & f worms used, $\mathrm{N}=$ & ${ }^{c d}$ dose ad & community; \\
\hline
\end{tabular}

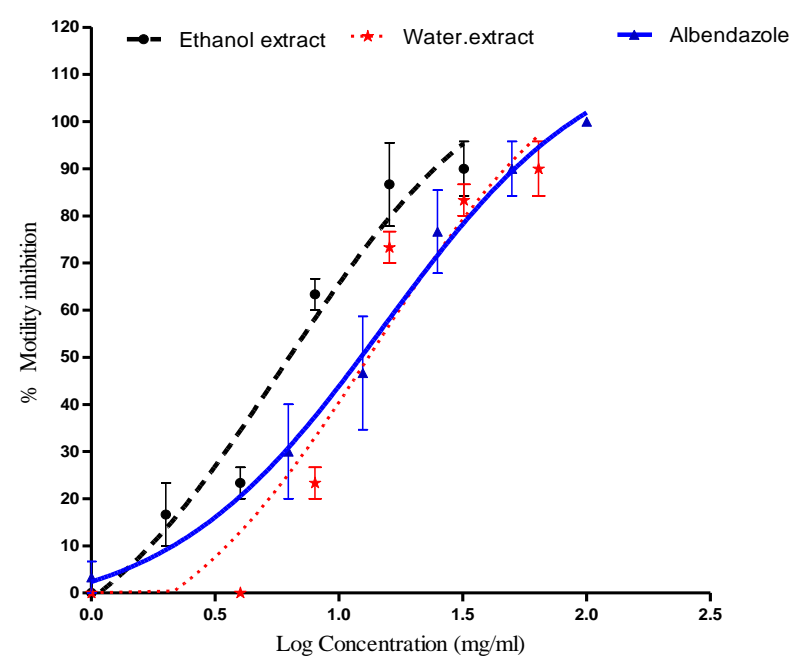

Fig 1: Dose-response curves of adult Ascaris suum motility inhibition by ethanol and water crude extracts of Vernonia amygdalina 48 hours post treatment.
Secamone Africana: The extracts of S.africana produced high worm motility inhibition proportions that were dose-dependent compared to the negative control group. The percent motility inhibition by different concentration of water and ethanolic extracts of Safricana are given in table 3. The highest concentration of the water and ethanol extracts inhibited $93.3 \%$ and $80 \%$ respectively compared with negative control. The dosage adopted by the community inhibited worm motility by $13.33 \pm 8.82$ percent of the parasites.

The dose response-curve of the ethanolic and water of S.africana crude extracts and albendazole revealed that the water extract was more potent than the ethanolic extracts compared with Albendazole as demonstrated by the shift of the water extract curve to the left of ethanolic extract (Figure 2). 
Agric. Biol. J. N. Am., 2013, 4(1): 54-66

Table 3: Effect of concentration of crude extracts of Secamone africana on motility of Ascaris suum48 hours post treatment

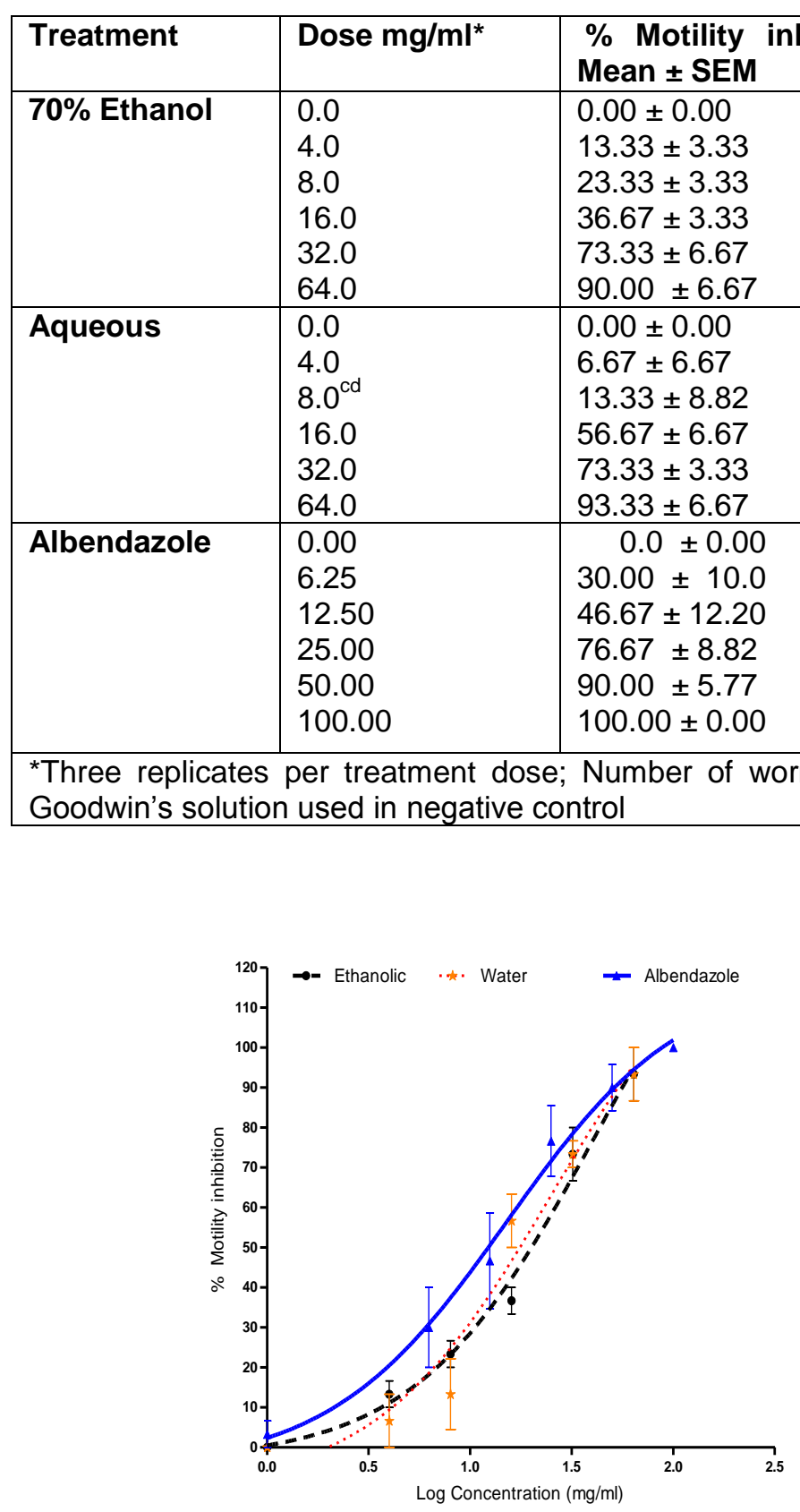

Fig 2: Dose-response curves of adult Ascaris suum motility inhibition by ethanol and water crude extracts of Secamone africana 48 hours post treatment

There was also a significant difference motility inhibition in all dose levels of both plant extracts that was dose-dependent irrespective of solvent used when compared with negative control observed using generalized linear model $\left(F_{(5,53)}=8.00, \quad P=0.001\right.$; $\left.\mathrm{R}^{2}=0.92\right)$. There was also a significant difference in potency of ethanol and water extracts of S.africana and albendazole $\left.\left(F_{(2,}{ }_{53}\right)=183.26, p=0.001\right)$. However, comparing the crude extracts on worm motility with $10 \%$ albendazole there was no significant difference $(p>0.05)$. A weak interaction between dose effect and the solvent used in extraction of active ingredients on motility inhibition was also observed $\left(F_{(10,53)}=2.657, p=0.015\right.$; $R^{2}=0.93$ ).

The median effective doses of the extracts compared with albendazole: The study revealed variation in median effective doses of the plant extracts. The median effective doses $\left(E D_{50}\right)$ of $V$. amygdalina and S.africana ethanol and water extracts are given in Table 4. V.amygdalina ethanol extract was more potent than water extract while the water extract of $S$. africana was more potent than ethanol extract. The two plant species $E_{50}$ were also different. 
Agric. Biol. J. N. Am., 2013, 4(1): 54-66

Table 4: The median effective doses $\left(E_{50}\right)$ of ethanolic and aqueous extracts of the crude plants' extracts 48 hours post treatment

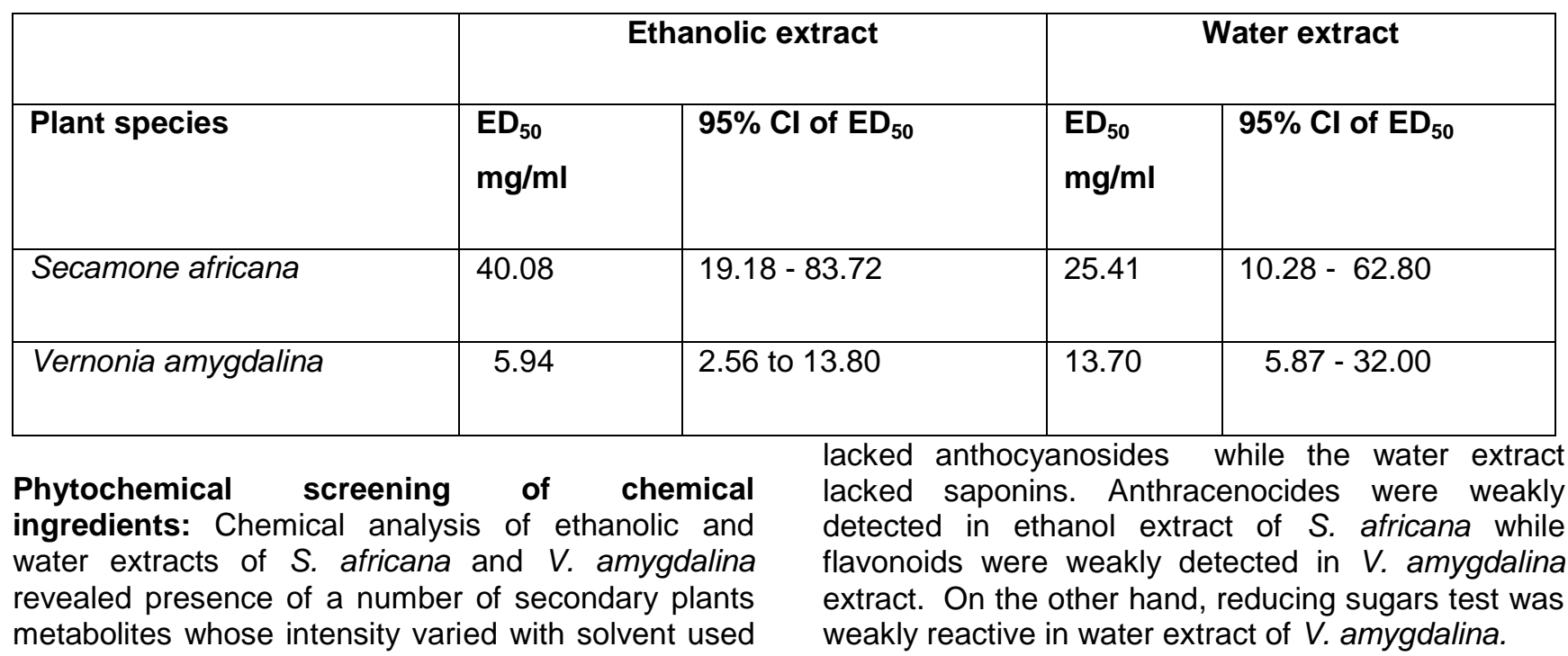

(Table 5). However, S. africana ethanol extract

Table 5. Phytochemical constituents of water and ethanol extracts of the five anthelmintic plants

\begin{tabular}{|l|c|c|c|c|}
\hline Compound & \multicolumn{2}{|c|}{ S. africana } & \multicolumn{2}{c|}{ V.amygdalina } \\
\hline & Water & Ethanol & Water & Ethanol \\
\hline Tannins & ++ & ++ & ++ & ++ \\
\hline Reducing sugars & ++ & ++ & + & ++ \\
\hline Saponins & - & $\mathrm{X}$ & +++ & $\mathrm{X}$ \\
\hline Alkalloid salts & ++ & ++ & ++ & ++ \\
\hline Anthracenosides & ++ & + & ++ & ++ \\
\hline Coumarin derivatives & ++ & ++ & ++ & ++ \\
\hline Flavonosides & ++ & ++ & ++ & + \\
\hline Steroid glycosides & ++ & ++ & ++ & ++ \\
\hline Triterpenes & ++ & ++ & ++ & ++ \\
\hline Anthocyanosides & ++ & - & ++ & ++ \\
\hline
\end{tabular}

Legend: (+) weakly present, (++) moderate, (+++) strongly present, (-) absent or

undetected, $(x)$ not tested in ethanol extract

\section{DISCUSSION, CONCLUSIONS AND RECOMMENDATIONS DISCUSSION}

The results of this study showed that V.amygdalina and S.africana have higher anthelmintic potential. The results of this study support the claims by the Nakasongola agro-pastoral farmers and previous reports that these plants treat helminths infections in livestock (Wasswa and Olila, 2006; Nalule et al., 2011). However, the community dosage effect was low by both plants probably indicating under dosing. This probably explains the persistent worm burden despite use of these herbs. This may lead to worm resistance.

Both the ethanolic and water extracts of $V$. amygdalina and $S$. africana inhibited Ascaris suum motility in a dose dependent response by paralyzing them or causing their death by 48 hours (table 2 and table 3) compared with albendazole. It was also evident that S.africana was less potent than V.amygdalina extracts, an activity that could be 
attributed to the lack of saponins and the anthocyanosides (Table 5) despite high yield in ethanol and water solvents.

The median effective dose $\left(E D_{50}\right)$ of ethanolic and water crude extracts of $V$. amygdalina and $S$. africana varied with solvent used in extraction of active ingredients with ethanolic extract of $V$. amygdalina and water extract of $S$.africana being the most potent despite comparable efficacies (Table 5). This could probably be related to the different chemical ingredients extracted in the different solvents and their biological effects on parasites. The variation in potency may also be attributed to source of parasites and previous exposure to the plants. Similar variation in potency and efficacy were observed by Gakuya (2001) and Costa et al. (2008) when they used different solvents for extraction of active ingredient and observed varying bioactivity results. Similarly, Tuwangye and Olila (2006) used methanol to extract $V$. amygdalina for anthelmintic bioassay and achieved $50 \%$ kill at $6 \mathrm{mg} / \mathrm{ml}$ and $\mathrm{ED}_{50}$ of 3.533 $\mathrm{mg} / \mathrm{ml}$, all different from the findings of this study. The study showed that efficacy of extracts increased with increasing concentration of extract. Increasing motility inhibition with increasing concentration could be due to the saturation of target receptors. Similar observation were made by Lullman et al. (1993) who said that the receptors get saturated with increasing dose of active ingredient that increases with incubation period. It is likely that at higher concentration all binding receptors on the worms were occupied thus leading to hyperpolarisation of membranes limiting excitation and impulse transmission causing flaccid paralysis of worm muscles, a similar observation made by Wasswa and Olila, (2006). This study revealed that despite the community having knowledge on use of the plants for helminthes control, they under dose the parasites. The low dose adopted by the agro-pastoral community could be responsible for the persistent helminths infections and low livestock productivity. Continued administration of low doses of plant crude extract to parasites may lead to risks of development of helminths resistance from repeated exposure to low doses.

The antihelmintic property of $V$. amygdalina was also observed when the juice from the leaves was found to reduce mixed infection worm egg production in goats by $64 \%$ using fecal egg reduction count test (Nalule et al., 2011b). Nfi et al. 1999 reported anthelmintic efficacy of $V$. amygdalina in ethnoveterinary to be $52.4 \%$. Alawa et al. (2010) when used V.amygdalina water extract at a dose concentration of $1.1 \mathrm{~g} / \mathrm{kg}$ body weight on calves naturally infected, achieved $59.5 \%$ reduction in eggs per gram (EPG) of faeces. However, Alawa et al. (2003) previously reported that the hot water extract did not possess anthelmintics effect in vitro fecal culture of eggs at concentrations up to $11.2 \mathrm{mg} / \mathrm{ml}$ against Haemonchus contortus and Trichostrongylos colubriformis and the author attributed it the high temperature subjected to the extract that could have degraded the active compounds in the leaves. A study by Huffman and Seifu, (1989) reported that the feacal egg count reduced from 130 to 15 within 24 hour post Chimpanzee chewing of the $V$. amygdalina pith. A study by Molgaard et al. (2001), using water extract of leaves, stem, root and root bark of $V$. amygdalina were able to kill cestodes of Hymenolepis diminuta after 24 hours of treatment. A recent study by Ademola and Eloff (2011), revealed a significant effects on different development stages of Haemonchus contortus that varied with solvent used for extraction of active ingredient.

The anthelmintic properties of V.amygdalina and S.africana crude extracts could be attributed to the variety of secondary metabolites present. Preliminary phytochemical screening of the plants extracts revealed presence of tannins, alkaloid salts, glycosides, triterpenoids, flavonoids, anthracenoides, anthracyanins, coumarin derivatives and saponins whose intensity varied among the ethanolic and water extracts (Table 5). Notwithstanding, Waterman (1992) reported that plant metabolites are unstable molecules and their biological activity are dependent on their structure, physical and chemical properties.

It is therefore possible that the parasite paralysis and/or death observed may have been attributed to secondary metabolites (Makut et al., 2008) like tannins, alkaloids salts and saponins among others. These plant metabolites may have worked singly or in combination to cause the motility inhibition, paralysis or death of the worms that was achieved in all the studied crude extracts. Kaufman et al. (1999) accredited the synergistic interactions to underlie the effectiveness of phyto-medicines that lead to better activity of some individual constituents. Briskin (2000) and Wynn and Fougere, (2007) acknowledged that the plant metabolites action may be additive, synergistic or antagonistic in manner acting at single or at multiple target sites. It is therefore likely that a number of compounds could have contributed to the anthelmintic activity observed in both plants'extracts. However, Engel (2007) reported that V. amygdalina 
contain seven steroid glycoside as well as four sesqueterpene lactones that could be attributed to the killing of the parasites that cause schistosomiasis, malaria and Leshmaniasis. In addition, the plant was reported to have high levels of vernoniaside B1 that may be toxic to animals (Engel, 2007). It is therefore likely that the worms in this study could have been killed by these compounds.

Nevertheless, it is well documented that some anthelmintic drugs like the benzimidazoles (BZD) kill the parasites by binding to a specific building block, the beta tubulin and prevent its incorporation into micro-tubules which are essential for energy metabolism (Schoenian, (2008). Barrowman et al. (1984) also reported that Benzimidazole anthelmintics act by interfering with the microtubule system in Ascaris suum. Thus, these compounds could have caused their effect through the same mechanism. Paralysis of worm tissues makes them unable to feed leading to death as result of lack of energy. It is also likely that alkaloids present in the plants could also have contributed to the paralysis and consequent death of the worms. The nematocidal activity of alkaloids had also been demonstrated by Satou et al. (2002) when they used two rat nematodes; Strongyloides ratti and S. venezuelensis models for human nematodes. Alkaloids salts on the other hand are competitive antagonists at muscarinic acetylcholine receptor preventing the binding of acetylcholine and are reportedly physiologically active with sedative and analgesic properties in addition to leading to excitation of cells and neurological dysfunction (Tarnopolsky and Beal, 2001). On the other hand the saponins present in the crude extract of V.amygdalina could have caused feed refusal and starvation of the parasites leading to their death from lack of energy thus the variation in potency compared with S.africana that lacked saponins. There is however, no literature on S.africana anthelmontic study for comparison with this study finding. Similar views on saponins' effects on feeding were held by Dalsgaard et al. (1990) and Francis et al. (2002) who also reported that saponins kill protozoans and mollusks. It is also probable that in vivo paralysis lead to loss of grip of parasites on the gut wall leading to the spontaneous expulsion of parasites together with feaces.

The roles of tannins in helminths control have been documented (Athnasiadou et al., 2001a; Molan et al., 2003a; Hoste et al., 2006; Cenci et al., 2007; Kotze et al., 2009; Forbey et al., 2009). The nematocidal activity of tannin extracts has also been reported with evidence of anthelmintic properties of condensed tannins by series of in vitro studies (Dawson et al., 1999; Athanasiadou et al., 2001a; Molan et al., 2003b; Ademola and Idowu, 2006) and in vivo studies (Athanasiadou et al., 2000; Butter et al., 2001; Paolini et al., 2003a and 2003b; Kotze et al., 2009). Chemically tannins are polyphenolic compounds (Bate-Smith, 1962) and synthetic phenolic anthelmintics like niclosamide and oxyclozanide are said to interfere with energy generation in helminths parasites by uncoupling oxidative phosphorylation (Martin, 1997). It is possible that tannins contained in ethanol and water extracts of plants produced similar effects. It was also suggested that tannins bind to free proteins in the gastrointestinal tract of host animal (Athnasiadou et al. 2001b; Hoste et al., 2006) or glycoprotein on the cuticle of the parasite disturbing the physiological functions like motility, feed absorption and reproduction (Thompson and Geary, 1995; Aerts et al., 1999; Githiori et al. 2006) or interference with morphology and proteolytic activity of microbes (Min et al., 2003; Waghorn and McNabb, 2003) and cause death.

The study further showed variation in potencies based on the $E_{50 \text { s }}$ obtained despite the many compounds that were extracted in the different extracts of the two plants. It is likely, only a few could be active as anthelmintics. The compounds could be specific to each plant structurally as an isomer or derivatives of the bigger molecules and their concentration in different plant species and plants parts could be different. Similar observations were made by Waterman et al. (2010). It is likely that the solvent used in extraction of active ingredients could be responsible for the crude extract potency. This is in agreement with observations made by Malu et al. (2009).

\section{CONCLUSION AND RECOMMENDATION}

The overall findings of the study showed that ethanolic and water extracts of $S$. africana and $V$. amygdalina, exhibit evidence of in vitro anthelmintic activity against Ascaris suum revealing the anthelmintic potential justifying their traditional ethnoveterinary use by the pastoral communities in the cattle corridor of Uganda. However, potency of plant extract was dependent on the solvent used to extract the active ingredients. Nevertheless, the community adopted dosage explicitly fell far below the required quantity to produce beneficial helminths control. Further studies are needed to determine, bioactivity 
in vivo and against other developmental stages of parasites in addition to determining the toxic effect in animals, bioavailability and bio-acceptability. Feasibility studies would give more insight into the recommendation for broader use or integrated into the current clinical treatments. There is also need to standardize and improve on the community adopted dose through intensive sensitization of stakeholders to harmonise the traditional knowledge and the scientific inference.

\section{ACKNOWLEDGEMENT}

The authors are grateful to the Regional Universities Forum (RUFORUM), Association of African Universities (AAU), and Makerere University for funding this study. We are also grateful to the Nakasongola agro-pastoral community who provided information on which this study was based.

\section{REFERENCES}

Abosi, A.O., Raseroka B.H (2003). In-vivo antimalarial activity of Vernonia amygdalina. British Journal of Biomedical Science 60 (2): 89-91.

Ademola, I.O and Idowu, S.O (2006). Anthelmintic activity of Leucaena leucocephala seed extract on Haemonchus contortus-infective larvae. The Veterinary Record, 158: 485-486.

Ademola, I.O and Eloff, J.N (2011). Anthelminthic activity of acetone extract and fractions of Vernonia amygdalina against Haemonchus contortus eggs and larvae, Tropical Animal Health and Production, 43 (2): 521-527.

Aerts, R.J., Barry,T.N and McNabb, W.C (1999). Polyphenols and agriculture: beneficial effects of proanthocyanidins in forages. Agricultural Ecosystems Environment, 75, 1-12.

Akah, P.A and Okafor, C.I (1992). Blood sugar lowering effect of Vernonia amygdalina (Del) in an experimental rabbit model. Phytotherapy Research, 6: 171-173.

Akinpelu DA (1999). Antimicrobial activity of Vernonia amygdalina leaves. Fitoterapia. J. Study. Med. Plants. 70(4): 432-440.

Alawa, C.B.I., Adamu, A.M., Gefu, J.O., Ajanusi, O.J., Abdu, P.A., Chiezey, N.P., Alawa, J.N and Bowman, D.D (2003). In vitro screening of two Nigerianmedicinal plants (Vernonia amygdalina and Annona senegalensis) for anthelmintic activity. Vet. Parasitol., 113: 73-81.

Alawa, C.B.I., Adamu, A.M., Gefu, J.O., Ajanusi, O.J., Abdu, P.A., Chiezey, N.P (2010). In vivo efficacy of Vernonia amygdalina (compositae) against natural helminth infection in Bunaji (Bos indicus) calves. Pakistan Veterinary Journal, 30 (4): 215-218.

Argheore, E. M., Makkar, H.P.S and Becker, K (1998). Feed value of some browse plants from the central zone of Delta State Nigeria. Tropical Science 38(2), pp. $97-104$.

Arhoghro EM, Ekpo KE, Anosike EO, lbeh GO (2009). Effect of water extract of bitter leaf (Vernonia amygdalina Del) on carbon tetrachloride (CCl4) induced liver damage in albino wistar rats. Eur. J.Sci. Res., 26: 122-130.

Asuquo OR, Edet, AG, Mesembe OE, Atanghwo JI (2010). Ethanolic Extracts Of Vernonia Amygdalina and Ocimum Gratissimum Enhance Testicular Improvement In Diabetic Wistar Rats. The Internet Journal of Alternative Medicine, 8:2.

Athanasiadou, S., Kyriazakis, I., Jackson, F., Coop, R.L (2001a). Direct anthelmintic effects of condensed tannins towards different gastrointestinal nematodes of sheep: in vitro and in vivo studies. Vet. Parasitol. 99: 205-219.

Athanasiadou, S., Kyriazakis, I., Jackson, F and Coop, R. L (2001b). The effects of condensed tannins supplementation of foods with different protein content on parasitism, food intake and performance of sheep infected with Trichostrongylus colubriformis. British Journal of Nutrition, 86: 697-706.

Athanasiadou ,S., Kyriazakis, I., Jackson, F and Coop, R. $L$ (2000). Consequences of long-term feeding with condensed tannins on sheep parasitized with Trichostrongylus colubriformis. International Journal for Parasitology, 30:1025-1033.

Barrowman, M.M., Marriner, S.E and Bogan, J.A (1984). The binding and subsequent inhibition of tubulin polymerization in Ascaris suum (in vitro) by benzimidazole anthelmintics. Biochemical Pharmacology, 33, (19): 3037-3040.

Bate-Smith, E .C (1962). The phenolic constituent of plants and their taxonomic significance, dicotyledons. Journal of The Linnean Society of London, Botany, 58, 95103.

Briskin, D.P (2000). Medicinal plants and phytomedicines: Linking plant Biochemistry and physiology to human health. Updates on phytomedicines. Plant physiology, 124: $507-514$.

Burkill, H.M., Dalziel, J.M and Hutchinson, J (1985). The useful plants of west tropical Africa. Royal Botanic Gardens, (Kew). Second edition. ISBN: 094764301X

Butter, N.L., Dawson, J.M., Wakelin, D and Buttery, P.J (2001). Effect of dietary condensed tannins on gastrointestinal nematodes. Journal of Agricultural Science 137, 461-469. 
Cenci, F.B., Louvandini, H., McManus, C.M., Dell'Porto, A., Costa, D.M., Araújo, S.C., Minho, A.P and Abdalla, AL (2007). Effects of condensed tannin from Acacia mearnsii on sheep infected naturally with gastrointestinal helminthes. Veterinary Parasitology 144 (2007) 132-137.

Ciulei, J (1964). Manual for analysis of vegetable drugs.

Costa, C.T.C., Bevilaqua, C.M.L., Camurça-Vasconcelos, A.L.F., Maciel, M.V., Morais, S.M., Castro, C.M.S., Braga, R.R and Oliveira, L.M.B (2008). In vitro ovicidal and larvicidal activity of Azadirachta indica extracts on Haemonchus contortus. Small Ruminant Research, 74, (1-3): 284-287.

Dalsgaard, K., Hilgers, L and Trouve ,G (1990). Classical and new approaches to adjuvant use in domestic food animals. Advances in Veterinary Science \& Comparative Medicine, 35, 121-160.

Dawson, J.M., Buttery, P.J., Jenkins, D., Wood, C.D and Gill, M (1999). Effects of dietary Quebracho tannin on nutrient utilisation and tissue metabolism in sheep and rats. Journal of the Science of Food and Agriculture, 79:1423-1430.

Donahue, M.J., Yacoub, N.J., Kaeini, M.R., Masaracchia, R.A and Harris, B.G (1981). Glycogen metabolizing enzymes during starvation and feeding of $A$. suum maintained in a perfusion chamber. J.parasitol. 67(4), 1981 pp 505-510.

Elujoba, A. A., Odeleye, O. M and Ogunyemi, C. M. 2005. Traditional medicine development for medical and dental primary health care delivery system in Africa. African Journal of Traditional, Complementary and Alternative Medicines. Vol. 2, Num. 1, 2005, pp. 46-61

Engel, C (2007). Zoopharmacology In: Wynn S.G, and Fougere (Eds). Veterinary Herbal medicine. (pp7-15). Library of Congress Cataloging-in Publication Data. ISBN: 10:0-323-02998-1. 695p.

Forbey, J. S., Harvey, A. L., Huffman, M.A., Provenza, F.D., Sullivan, R and Tasdemir D 2009. Exploitation of secondary metabolites by animals: A response to homeostatic challenges. Integrative and Comparative Biology. 49 (3): 314-328.

Francis, G., Kerem, Z., Makkar, H. P. S and Becker, K (2002). The biological action of saponins in animal systems: a review. British Journal of Nutrition, 88: 587-605. doi: 10.1079/BJN2002725

Gakuya, D.W. (2001). Pharmacological and clinical evaluation of the anthelmintic activity of Albizia anthelmintica Brogn, Maerua edulis De wolf and Maerua subcordata De wolf plant extracts in sheep and mice. PhD Thesis, University of Nairobi.

Gill, J.H., Redwin, J.M., van Wyk, J.A and Lacey, E (1991). Detection of resistance to ivermectin in Haemonchus contortus. Int J Parasitol 21:771-776.
Githiori, J.B., Athanasiadou, S and Thamsborg, S. M. (2006). Use of plants in novel approaches for control of gastrointestinal helminths in livestock with emphasis on small ruminants. Veterinary Parasitology, 139 (4): 308-320.

Hamill, F.A., Apio, S., Mubiru, N.K., Bukenya-Ziraba, R., Mosango, M., Maganyi, O.W. and Soejarto, D.D (2003). Traditional herbal drugs of southern Uganda, 2: literature analysis and antimicrobial assays. Journal of Ethnopharmacology 84: 57-78.

Harborne, J. B. (1973). Phytochemical Methods. Chapman and Hall, London p. 113.

Hoste, H., Jackson, F., Athanasiadou, S., Thamsborg, S .M. and Hoskin, S .O. 2006. The effects of tannin-rich plants on parasitic nematodes in ruminants. Trends in Parasitology, 22 (6): 253-261.

Huffman, M.A and Seifu, M (1989). Observations on illness and consumption of a possibly medicinal plant Vernonia amygdalina (Del.), by a wild Chimpanzee in the Mahale Mountains National park, Tanzania. In: Primates, 30(1): 51-63, January, 1989.

Huffman, M.A (2003). Animal self-medication and ethnomedicine: Exploration and exploitation of medicinal properties of plants. Proceedings of the Nutrition Society, 62:371-381.

Izevbige, E.B., Bryant, T.L and Walker, A (2004). A novel natural inhibitor of extracellular signalregulated kinases and human breast cancer cell growth. Experimental Biology and Medicine (May Wood), 229 (2): 163-169.

Kamatenesi-Mugisha, M and Oryem-Origa, H. (2007). Medicinal plants used to induce labour during childbirth in western Uganda. Journal of Ethnopharmacology 109 (2007) 1-9.

Katende, A.B., Birnie, A and Tengnas, B (1995). Useful Trees and shrubs for Uganda. Identification, propagation and management for Agricultural and livestock communities. Technical Handbook No. 10. Regional Soil Conservation Unit, RSCU, 1995

Kaufman, P.B, Cseke LJ, Warber S, Duke JA, Brielmann H.L. 1999. Natural Products from Plants. CRC Press, Boca Raton, FL

Kémeuzé, V.A., 2010. Secamone afzelii (Schult.) K.Schum. [Internet] Record from Protabase. Schmelzer, G.H. \& Gurib-Fakim, A. (Editors). PROTA (Plant Resources of Tropical Africa / Ressources végétales de l'Afrique tropicale), Wageningen, Netherlands. < http://database.prota.org/search.htm>. Accessed 27 February 2011.

Kotze, A. C., Clifford S., O'Grady, J., Behnke, J. M. and McCarthy, J. S (2004). An in vitro larval motility assay to determine anthelmintic sensitivity for human 
hookworm and strongyloides species. Am. J. Trop. Med. Hyg., 71(5):608-616.

Kotze, A. C., O'Grady, J., Emms J., Toovey, A. F., Hughes, S., Jessop, P., Bennell, M., Vercoe, P.E. and Revell, D.K (2009). Exploring the anthelmintic properties of Australian native shrubs with respect to their potential role in livestock grazing systems. Parasitol. 136 (9):1065-80.

Kupcham, S.M (1971). Drugs from Natural Products. Plant source in drugs discovery, science and development. American Chemical Society, 6: 311-318.

Lamson, P.D and Brown, H.W (1936). Methods of testing the anthelmintics properties of asacriciedes. American Journal of Hygiene, 23:85-103.

Lullman, H.K., Morh and Bieger, D (1993). Colour Atlas of pharmacology, Theme medical publisher, Inc. New York, pp: 52-98.

Makut, M.D., Gyar, S.D., Pennap, G.R.I and Anthony, D (2008). Phytochemical screening and antimicrobial activity of ethanolic and methanolic extracts of leaf and bark of Khaya senegalensis. African Journal of Biotechnology. Vol.7 (99): 1216-1219.

Malu, S. P., Obochi, G. O., Edem C. A and Nyong, B. E (2009). Effect of methods of extraction on phytochemical constituents and antibacterial properties of Tetracarpidium conophorum seeds. Global Journal of Pure and Applied Sciences, 15 (3): 373-376.

Marie-Magdeleine, C., Hoste, $\mathrm{H}$. , Mahieu, M., Varo, $\mathrm{H}$ and Archimede, H (2009). In vitro effects of Cucurbita moschata seed extracts on Haemonchus contortus. Veterinary Parasitology 161, 99-105.

Martin, R.J (1997). Modes of action of anthelmintic drugs. The Veterinary Journal, 154, 1, 11-34.

Min, B. R., Barry, T. N., Attwood, G. T., and McNabb, W. C (2003). The effect of condensed tannins on the nutrition and health of ruminants fed fresh temperate forages: a review. Animal Feed Science and Technology, 106, 3-19.

Mojab, F., Kamalinejad, M., Ghaderi, N. and Vahidipour, H. R (2003). Phytochemical Screening of Some Species of Iranian Plants. Iranian Journal of Pharmaceutical Research, 77-82.

Molan, A. L., Duncan, A.J, Barry TN and McNabb, W.C (2003a). Effects of condensed tannins and crude sesquiterpene lactones extracted from chicory on the motility of larvae of deer lungworm and gastrointestinal nematodes. Parasitology International, 52: 209-218.

Molan, A.L., Meagher, L.P., Spencer, P.A and Sivakumaran, $S$ (2003b). Effect of flavan-3-ols on in vitro egg hatching, larval development and viability of infective larvae of Trichostrongylus colubriformis. International Journal for Parasitology, 33:1691-1698.

Molgaard, P., Nielsen, S.B., Rasmussen, D.E., Drummond, R.B., Makaza, N and Andreassen, J (2001). Anthelmintic screening of Zimbabwean plants traditionally used against schistosomiasis. J. Ethnopharmacol., 74:257-264.

Nalule, A. S., Karue, C. N and Katunguka-Rwakishaya, E (2011b). Anthelmintic activity of Phytolacca dodecandra and Vernonia amygdalina leaf extracts in naturally infected small East African goats. Livestock Research for Rural Development 23 (12) 2011

Nalule, A.S, Mbaria, J. M., Olila, D and Kimenju, J. W (2011a). Ethnopharmacological practices in management of livestock helminthes by pastoral communities in the drylands of Uganda; Livestock Research for Rural Development, 23(2) 2011

Nfi, A., Ndi, C., Bayemi, P.H., Njwe, R., Tchoumboue, J., Njakoi, H., Mopoi, N., Njakoi, M and Sali Django (1999). The anthelmintic efficacy of some indigenous plants in the northwest province of Cameroon, Rev. Elev. Méd. Vét. Pays Trop. 5, 103-106.

Ojiako, O. A and Nwanjo, H. U (2006). Is Vernonia amygdalina hepatotoxic or hepatoprotective? Response from biochemical and toxicity studies in rats. African Journal of Biotechnology Vol. 5 (18):1648-1651.

Paolini, V., Frayssines A., De La Farge, F., Dorchies, P and Hoste, $H$ (2003b). Effects of condensed tannins on established populations and on incoming larvae of Trichostrongylus colubriformis and Teladorsagia circumcincta in goats. Veterinary Research, 34, 331339.

Paolini, V., Fouraste, I and Hoste, H (2004). In vitro effect of three woody plants and sainfoin extracts on $3^{\text {rd }}$ stage larvae and adult worms of three gastrointestinal nematodes. Parasitology, 129, (01), 69 -77.

Paolini, V., Bergeaud, J. P., Grisez, C., Prevot, F., Dorchies, Ph and Hoste, H (2003a). Effects of condensed tannins on goats experimentally infected with Haemonchus contortus. Veterinary Parasitology, 113 (3-4):253-261.

Satou, T., Koga, M., Matsuhashi, R., Koike, K., Tada, I and Nikaido, T (2002). Assay of nematocidal activity of isoquinoline alkaloids using third stage larvae of Strongyloides ratti and $S$. venezuelensis. Veterinary Parasitology, 104: 131-138.

Schoenian, S (2008). Understanding anthelmintics (dewormers). Small Ruminant Info Series. Western Maryland Research \& Education Center, University of Maryland Cooperative Extension. 
Siamba, D.N., Okitoi, L. O., Watai M. K., Wachira, A .M. Lukibisi, F. B. and Mukisira, E A (2007). Efficacy of Tephrosia vogelli and Vernonia amygdalina as anthelmintics against Ascaridia galli in indigenous chicken. Livestock Research for Rural Development 19 (12) 2007

Tabuti, J.R.S (2009). Fodder plants for cattle in Kaliro district, Uganda. 161African Study Monographs, 30(3): 161-170.

Tarnopolsky, M. A and Beal, M. F (2001). Potential for creatine and other therapies targeting cellular energy dysfunction in neurological disorders. Annals of Neurology, 49: 561-574.

Tchamadeu, M.C., Dzeufiet, P.D.D., Kouambou, N.C.C., Azebaze, A.G.B., Allard, J., Girolami, J.P., Tack, I., Kamtchouing, P., Dimo, T., 2010. Hypoglycaemic effects of Mammea africana (Guttiferae) in diabetic rats. Journal of Ethnopharmacology, 127, 368-372. doi:10.1016/j.jep.2009.10.029.

Thompson, D. P and Geary, T. G (1995). The structure and function of helminth surfaces. In: Marr J.J, (Eds). Biochemistry and Molecular Biology of Parasites. 1st Ed. New York: Academic Press 203-32.

Tuwangye, I and Olila, D (2006). The Anthelmintic Activity of Selected Indigenous Medicinal Plants Used by The anyankole of Western Uganda . Journal of Animal and Veterinary Advances, 5: 712-717.

Waghorn, G.C and McNabb, W.C (2003). Consequences of plant phenolic compounds for productivity and health of ruminants. Proceedings of the Nutrition Society, 62, 383-392.

Wasswa, P and Olila, D (2006). The in vitro Ascaricidal activity of selected indigenous medicinal plants used in ethno veterinary practices in Uganda. Afr. J. trad. CAM 3: $94-103$

Waterman, C., Smith, R.A., Pontiggia, L and DerMarderosian, A (2010). Anthelmintic screening of Sub-Saharan African plants used in traditional medicine. Journal of Ethnopharmacology 127 755-759.

Waterman, C., Smith, R. A., Pontiggia, L and DerMarderosian, A (2010). Anthelmintic screening of Sub-Saharan African plants used in traditional medicine. Journal of Ethnopharmacology, 127 (3): 755-759.

Waterman, P.G (1992). Role for secondary metabolites in plants. Ciba Foundation symposia, 171, 255 - 275.

Wynn S.G., and Fougere B J., 2007. Introduction: Why use herbal medicine. In: Wynn S.G, and Fougere (Ed). Veterinary Herbal medicine. Library of Congress cataloging-in publication data. ISBN: 10:0-323-029981. p 695 .

Yeap, S.K., Ho, W.Y., Beh, B .K., Liang, W. S., Ky, H., Yousr, A. H. N and Alitheen, N. B

(2010). Vernonia amygdalina, an ethnoveterinary and ethnomedical used green vegetable with multiple bioactivities. Journal of Medicinal Plants Research Vol. 4(25), pp. 2787-2812.

Zabri, H., Kodjo, C., Benie, A., Bekro, J.M and Bekro, Y. A (2008).Phytochemical screening and determination of flavonoids in Secamone afzelii (Asclepiadaceae) extracts. African Journal of Pure and Applied Chemistry Vol. 2 (8), pp. 080-082. 